Covered in: ERIH PLUS, CEEOL, Index Copernicus, CrossRef, CrossCheck, J-Gate, Google Scholar, Ideas RePeC, Econpapers, Socionet, KVK, WorldCat.

\section{Learning to Learn: Critical Thinking Skills to Help Students for Life}

\section{Cristina TRIPON1}

${ }^{1} \mathrm{PhD}$. Assistant Lecturer, Politehnica University of Bucharest, Department of Teaching Career Teacher Training and Social Sciences Department, Romania, cristina.tripon@upb.ro.

\begin{abstract}
With the last two decades, critical thinking has become imperative for integrated students at the workplace. Critical thinking includes the component skills of analyzing arguments, making inferences using inductive or deductive reasoning, judging or evaluating, making decisions or solving problems. Involves both cognitive skills and dispositions, which can be seen as attitudes or habits of mind, include flexibility, a propensity to seek reason, a desire to be well informed, a respect for and willingness to entertain different viewpoints.

This paper describes a study to investigate the impact of critical thinking strategies applied to work with students, to develop critical thinking skills. The research was conducted about 6 months, in a technical university, focuses on developing critical thinking skills in part by using complex contextualized problems. Upon conclusion of the study and analysis of the data, we observed significant gain in those skills, measured with the standard instrument: Watson Glaser Critical Thinking Appraisal (WGCTA).

The WGCTA has been used to compare students on entry and exit program, make comparisons between different levels and investigate the correlation between critical thinking and variables. All test items include problems and arguments based on situations experienced in the daily workplace, classrooms, social media and others. The tool has five subsets designed to evaluate different elements of critical thinking, comprise deduction, inference, the relevance of assumptions, interpretation, and evaluation of arguments.
\end{abstract}

Keywords: critical thinking skills; Watson Glaser Critical Thinking Appraisal; learning to learn.

How to cite: Tripon, C. (2018). Learning to Learn: Critical Thinking Skills to Help Students for Life. Logos Universality Mentality Education Novelty: Philosophy \& Humanistic Sciences, 6(2), 1-10. https://doi.org/10.18662/lumenphs/06 


\section{Introduction}

We live in a century of unlimited speed, technology and excessive information that overwhelm us all the time. Technology is progressing, trades are changing, and today's students need to be able to cope with progress, but above all market demands. Learning is a complex cognitive process and an intro- and interpersonal social activity; the teacher is no longer the magician who conveys information and shapes brains, forms skills, and characters.

In the third millennium, students form transferable skills, assume roles in a team, develop prosocial behavior, develop the competence to learn to learn, develop conceptual maps, develop critical and creative thinking.

\section{Problem statement}

One of the solutions proposed by many specialists (E. Păun, C. Cucoş, M. Taylor etc.), Stan (2004) believes it seems to be the postmodernization of the school, the changes of the teachers' conception regarding their role and the school, accepting students' individuality with everything they have today. The postmodern concept of the world allows educators to conceive a way out of the confusion of contemporary education, which is too often characterized by violence, bureaucracy, curricular stagnation, depersonalized assessment, political conflict, economic crisis, infrastructure decline, emotional fatigue, demoralization and lack of hope.

The analysis of the school from the perspective of the postmodern paradigm will bring a clearer understanding of the changes to which the whole school environment needs to adapt.

Postmodernism imposes in education a new paradigm, the existential humanist one, which puts the individual / individual student in the center of its preoccupations.

The paradigm, which brings great changes of emphasis in education, the way of realizing the fundamental processes in the school and the relations between them, is the constructivist paradigm.

Constructivism is a theory of knowledge with a long past. The roots of this theory are found in philosophy (Kant, Schopenhauer, Nietzsche) where they have proliferated in sociology, psychology, linguistics. Today it is a paradigm that interprets almost all social fields, from education to politics, from art to economy.

The success of constructivist vision today is due to the specificity of society, Siebert (2001) believes that constructivist thinking seems to be 
fashionable in a time when traditional certitudes and truths become fragile and questionable.

The constructivist paradigm has also contaminated the school environment, from the design of learning to the teaching staff and the organization of the school.

In fact, the constructivist vision "shatters" the established truths throughout the time; knowledge brings certainties and rewards, etc.) and puts into practice the ability to adapt to the new both students, especially teachers.

Siebert (2001) points out that from a constructivist point of view, education emphasizes the alienation, the dispositions, the uncertainties, the fundamental contingencies within the human relationship with the worlds with which it comes into contact. This is why the old belief in education overthrows that education is the one that gives man safety, strength, the ability to dominate and understand the world.

The constructivist perspective actually affirms the impossibility of definite and definitive knowledge, knowledge is not a product, it is rather a process, knowledge is a way we do not know exactly where it ends, it is a way that opens as we go, as it is expressed Francisco Varela (1991). Knowledge is a construct that each of us reinvented, redefined, rebuilt continuously as we accumulate new information, learning experiences in different contexts, school, and extra-curricular contexts.

From a constructivist perspective in education and learning are important questions, doubts, misunderstandings, hidden meanings, latent behind a certain understanding. For a long time school, teachers, parents have endeavored to offer models that are worthwhile to follow, ways to solve problems and solutions for failures.

In this particularly suggestive way is the critique of Neil Postman (2007) of the traditional school, referring to the manual as transmitting only certainties, not questions or doubts, the feeling of the provisions, the uncertainty or the ambivalence of the knowledge of the human being. Knowledge is offered as a product you can acquire, not as a permanent endeavor to overcome errors.

Lipset (1995) says that this competence (critical thinking) enters into that of a modern city, that is, a process at the end of which a group reaches consensus through discussion, debate, and analysis. The decision-making act should be more than just the accumulation of opinions expressed. Opinions must be confronted in the public sphere, and all participants in the public discourse must carefully listen to each other's arguments. To make authentic democratic decisions, no group should be excluded. 
In the educational field, John Dewey (Fisher, 2001) proposes the term reflexive thinking in his book How We Think (1909) as "a number of features that distinguish the superior use of the rational faculty of people it is minimal and routine functioning." The author uses the term "reflexive thinking" to describe this concept as an active, careful and persuasive consideration of an opinion or any form of knowledge in the light of the evidence they support and the conclusions they wish to base.

Developing Critical Thinking Competence involves taking several steps, including:

1) "from personal reactions to publicly supported ideas with convincing arguments";

2) "from respect for the ideas of others to self-confidence, in their own ideas based on arguments";

3) "from intuitive to logical";

4) "from a single perspective to multiple perspectives in addressing a problem".

Woods \& Walton (1992) believe that critical thinking cultivates abilities such as removing blurring and ambiguity of expression, recognizing the strengths or weaknesses of an argument; the ability to identify the evidence behind the support, the ability to identify the conclusions or the main line of argumentation in the verbosity of the dialogue; the ability to critically discern between the various problematic and unproblematic arguments in the argument.

\section{Research Questions}

The aim of the study is to demonstrate that the development of $21 \mathrm{st}-$ century competencies in students, especially critical thinking skills, can be organized in the ordinary teaching activities, but capitalizing on challenging learning designs for students.

To achieve the goal, the underlying research hypothesis assumed that the subjects in the experimental group who would follow the Fake newsWrong news module to post-test statistically significantly higher results in the Watson-Glaser Critical Thinking test than the subjects in the group control (posttest).

\section{Research Methods}

For the analysis of the quantitative data obtained in the experimental research, the SPSS (Statistical Package for Social Sciences) version 20 was used. The statistical hypothesis testing was performed using the 
Kolmogorov-Smirnov or Shapiro-Wilk test, the Anova Multiple Measures tests, t-test for independent samples, Bonferroni tests.

The Mann-Whitney test (or Wilcoxon-Mann-Whitney) is sometimes used in clinical experiments to compare the effectiveness of two treatments. It is an alternative to the t-test if the data does not have a normal distribution. While the t-test is relevant for the population average, MannWhitney is commonly used for population medians. The Mann-Whitney test is used as an alternative to the t-test when the data does not have a normal distribution. The test can detect differences in both form and spread, as well as the median. ANOVA test repeated measurements. Despite the name, it is also a statistical test used to determine the significance of the difference in the difference between three or more samples (dependent or independent) measured on a proportional scale.

The study included 120 students from the Polytechnic University of Bucharest, the second year, a license level. Of these, 60 were represented in the experimental group, which intervened with didactic activities developed to solve concrete problems, case studies and 60 were the control group, which did not intervene in any sense. Both research groups were tested at the beginning of the program and at the end of the program. The experimental group participated in 14 activities (every 120 minutes each), all belonging to the experimental module "Fake news-wrong news". In the experimental group, 47 subjects were boys and 13 were girls, in the control group 49 subjects were boys and 12 girls. The results of gender-based research have not been analyzed, but have been analyzed in their entirety. The entire research population benefits from the same teachers, as well as the same teaching styles, important to mention especially to eliminate any risk that could lessen the results of the research.

In order to establish internal consistency and confirm the analysis factors, we analyzed the results of the whole research group. In order to establish the test-retest and to revalidate the research tool, the results of the participants during the two sessions were considered. We did not evaluate participants who did not lend creditors to the examiner or those who did not attend the second session. Participants were examined individually or in small groups, with anonymity being kept. No time limit was imposed. The data were collected by 2 independent operators to avoid subjectivism.

\section{Findings}

The results obtained are analyzed in the following. Research hypothesis, those in the experimental group who will follow Fake news- 
Wrong news will have statistically significantly higher results in the WatsonGlaser Critical Thinking posttest test than the posttest test subjects follow to be studied.

From the Critical thinking Tests of Normality Table 1, the Kolmogorov-Smirnov and Shapiro-Wilk test results will be observed. For the variable to be normally distributed in the population, they must be insignificantly statistically. The result of the first test, Kolmogorov Smirnov, for the experimental group, pretest, is $0.122, \mathrm{p}=0.200$ and the result for Shapiro Wilk $=0.958, \mathrm{p}=0.330$. For the same group, after the intervention, the results obtained in the first test were 0.113 , with $\mathrm{p}=0.200$, Shapiro Wilk $=0.985, \mathrm{p}=0.272$. For the control group, the pretest time has $\mathrm{KS}=0.146$, $\mathrm{p}=0.200, \mathrm{SW}=0.915, \mathrm{p}=0.365$ and for the posttest test result $\mathrm{KS}=$ $0.122, \mathrm{p}=0.200, \mathrm{SW}$ test result $=0.958, \mathrm{p}=0.330$. As all the results obtained for each group, both in the pre-intervention and post-intervention phase, both in the Kolmogorov-Smirnov and Shapiro-Wilk tests, are statistically insignificant, it follows that the variables are normally distributed, which is apply ANOVA tests.

Table 1. Critical thinking Tests of Normality

\begin{tabular}{lllllll}
\hline & $\begin{array}{l}\text { Kolmogorov- } \\
\text { Smirnov }\end{array}$ & \multicolumn{5}{l}{$\begin{array}{l}\text { Shapiro- } \\
\text { Wilk }\end{array}$} \\
\hline & Statistic & df & Sign. & Statistic & df. & Sign \\
\hline pre.test.experim & .122 & 60 & .200 & .958 & 60 & .330 \\
posttest.experim & .113 & 60 & .200 & .985 & 60 & .272 \\
pretest.control & .146 & 60 & .200 & .915 & 60 & .365 \\
posttest.control & .122 & 60 & .200 & .958 & 60 & .330 \\
& & & & & & \\
\hline
\end{tabular}

The ANOVA critical thinking-Descriptive Table 2 presents the standard averages and deviations for each of the working groups, both at pretest and posttest. Therefore, we have the average 41.2857 for the experimental group - pretest, the average 51.8214 for the post-experimental group, for the control group we have at the time the average 40.7679 and the posttest 41.2857. As can be seen in the moments after the intervention, for the working group (experimental), it has the highest averages. 
Table 2. ANOVA critical thinking-Descriptive

\begin{tabular}{llll} 
& Mean & Std.Deviation & N \\
& & & \\
\hline pretest.experim. & 41.2857 & 1.95044 & 60 \\
posttest.experim. & 51.8214 & 2.09149 & 60 \\
pretest.control & 40.7679 & 1.61292 & 60 \\
posttest.control & 41.2857 & 1.95044 & 60
\end{tabular}

In Critical thinking - Mauchly's Test of Sphericity, the condition of sphericity, one of the conditions for applying the Anova repeat measurement test, is checked. Since the result of the Mauchly $\mathrm{W}=0.770$ test is statistically insignificant, we have fulfilled the condition of sphericity. The Critical Thinking Table of Tests of In-Subjects Effects-Table 3 is the main table in the output, containing the results of the general $\mathrm{F}$ tests. As $\mathrm{F}=$ 306.801, $\mathrm{p}=0.00$, being significant, there are significant differences between the 6 conditions regarding the development of competence critical thinking. In order to find out which of these conditions are differences, we will apply posthoc tests, namely Bonferonni.

Table 3. Critical Thinking Table of Tests of In-Subjects Effects

\begin{tabular}{|c|c|c|c|c|c|c|}
\hline & Source & $\begin{array}{l}\text { Type III } \\
\text { Sum of } \\
\text { Squares }\end{array}$ & df & $\begin{array}{l}\text { Mean } \\
\text { Square }\end{array}$ & $\mathrm{F}$ & Sig \\
\hline \multirow{5}{*}{$\begin{array}{l}\text { Critica } \\
\text { l.think } \\
\text { ing }\end{array}$} & Sphericity & 6912.079 & 5 & 1382.416 & 306.801 & .000 \\
\hline & Assumed & & & & & \\
\hline & $\begin{array}{l}\text { Greenhouse } \\
\text {-Geisser }\end{array}$ & 6912.079 & 3.334 & 2073.058 & 306.801 & .000 \\
\hline & $\begin{array}{l}\text { Huynh- } \\
\text { Feldt }\end{array}$ & 6912.079 & 3.860 & 1790.518 & 306.801 & .000 \\
\hline & $\begin{array}{l}\text { Lower- } \\
\text { bound }\end{array}$ & 6912.079 & 1.000 & 6912.079 & 306.801 & .000 \\
\hline \multirow{5}{*}{$\begin{array}{l}\text { Error( } \\
\text { critical } \\
\text {.thinki } \\
\text { ng) }\end{array}$} & Sphericity & 608.296 & 135 & 4.506 & & \\
\hline & Assumed & & & & & \\
\hline & $\begin{array}{l}\text { Greenhouse } \\
\text {-Geisser }\end{array}$ & 608.296 & 90.025 & 6.757 & & \\
\hline & $\begin{array}{l}\text { Huynh- } \\
\text { Feldt }\end{array}$ & 608.296 & 104.230 & 5.836 & & \\
\hline & $\begin{array}{l}\text { Lower- } \\
\text { bound }\end{array}$ & 608.296 & 27.000 & 22.529 & & \\
\hline
\end{tabular}


The results of the contrast tests are significant between the pretest and the posttest test time for the experimental group. Of course, there are other differences between the other moments between groups, but the selection is made according to the degree of interest of certain data shown in the research. Hence, the assumptions are confirmed. The results of Bonferonni post hoc tests are statistically significant. We note that there are significant differences between pretest and posttest experimental test group Bonferonni $\mathrm{t}=25.51, \mathrm{p}=0.000$, between pretest experimental group condition and pretest Bonferonni control group $\mathrm{t}=0.0520, \mathrm{p}=0.000$, between posttest test experiment group and pretest group control Bonferonni $\mathrm{t}=26.674, \mathrm{p}=0.000$, between posttest test group experiment and posttest test group Bonferonni $=25.51, \mathrm{p}=0.000$, between pretest test group and post test experimental group Bonferonni $=24.67, \mathrm{p}=$ control group and posttest experimental group Bonferonni $=25.51, \mathrm{p}=0.000$. There are no significant differences between the control group prestest condition and the Bonferonni control group posttest test $=1.04, \mathrm{p}=1000$.

As can be seen, there are significant differences between the two groups, both in pre-intervention and after an intervention. It can also be emphasized that the experimental group and the control group at the time of pretest developed the critical thinking competence approximately equal, but in the posttest phase the results no longer show this, but the posttest of the experimental group has values much higher than at pretest, which demonstrates that the Fake news-Wrong news activities have had the expected results.

Knowing that Bonferonni post hoc tests revealed that there are significant differences between the pretest and posttest conditions for the working group, it is necessary to calculate the effect size. We can calculate the effect size using the formula $r=\sqrt{ }$ (s.) $F /(F+d f R$, where $F$ is the result of the contrast test $F$ and $d f R$ is number of sub-units

The results obtained for pretest and posttest experimental group conditions are as follows $r=\sqrt{ }(\mathrm{s}) 650.699 /(650.699+27)$, that is, $r=0.96$

\section{Conclusions}

To test the effect of the Fake news-Wrong news module of learning on the development of critical thinking skills, the ANOVA method with repeated measurements was applied to the students. The results indicate that the passage of such a module had a strong effect on the development of the critical thinking skills in the experimental group, $F=650.699, p<0.001$, the effect size $r=0.96$, but not a significant development of these skills in the 
case of the group control (pretest and posttest). If we compare with the results of the pretest and posttest test group $\mathrm{F}=1.094, \mathrm{p}=0.305$, then we realize that the experimental way has had strong effects on the development of critical thinking skills for the participating subjects. In the past, education involved teaching knowledge, but now it's about helping the student find their own strategy to use to develop and build a path in an increasingly insecure, volatile, and ambiguous world. Given that we do not know what the future holds, it is important to capitalize on our own mistakes and failures, to reflect on them and, above all, to create learning and development contexts. Generations ago, teachers would have expected the ones taught to last a lifetime for their students. Today, however, schools have to prepare students for faster economic change than ever before, prepare them for jobs that have not yet been created, technologies that are about to be invented and solve social problems that they are not yet I found out.

School is probably the most important institution that can provide immense populations with the necessary levers for developing and transferring the knowledge, skills, attitudes that are so necessary for the development of the sustainable community. Although at an early stage in Romania, sustainable learning in the sense of learning to learn (in the long run) is the critical point on which stakeholders should continually reflect, improve their existing practices, making others more suited to the needs of society, but to be strongly focused on the sustainable economy.

The teacher's dilemma is to develop types of skills that are easy to transfer from one domain to another since it is the task of the students to select information as their access points are multiple. Half of the jobs we know in OECD countries can be achieved through digital technologies. The challenge is not the possession of information, it is precisely what can be done with it. In the context described, it is imperative to develop the skills of thinking and adaptation to develop a sustainable future of creativity, to develop decision-making exercises, to develop team working methods, to collaborate, to develop strategies for processing information and the ability to recognize their potential for creating new ways of working through the restructuring of school curricula, working methods in class as well as the entire learning experiences offered in educational institutions. Education recipients must become active citizens of society, be trained to solve real-life problems, develop critical thinking, develop effective communication skills, develop social and emotional skills that help people live and work together, etc. Such an investment in education, if we look at it in the cyclical spirit, would return to society in the form of citizens who participate effectively 
and innovate in the country's economic development. The restructuring of educational policies in the field, the responsible management of existing resources, the close cohesion of the decision-makers of the society determine the medium and long-term performances of sustainable development and implicitly a society with fewer elements "the problem" that poverty, pollution, school dropout, social problems, etc.

This module can provide better examples for activities that encourage critical thinking, social critique, and local context analyzes. Involves discussing, analyzing and applying values. The disconnection between curriculum and community life is a factor for children and adolescents to drop out of school. Unfortunately, school dropout is a problem around the world. One reason for abandonment is that students or their parents do not perceive education as relevant to their lives.In such a socio-educational context, the school, through its functions, is the only one able to form innovative citizens, adaptable to the needs described above, and to abandon an over-crowded curriculum, irrelevant from the perspective of student development.

\section{References}

Fisher, A. (2001). Critical thinking. An introduction. Cambridge, UK: Cambridge University Press.

Lipset, S. M. (Ed.). (1995). The encyclopedia of democracy. Washington, D.C., USA: Congressional Quarterly.

Postman, N. (2007). Postman - Bullshit and the art of crap detection. Retrieved from http://criticalsnips.wordpress.com/2007/07/22/neil-postman-bullshitand-the-art-of-crap-detection/

Siebert, H. (2001). Învățarea autodirijată şi consilierea pentru învătare [Self-directed learning and learning counseling]. Iaşi, România: Editura Institutul European.

Stan, E. (2004). Pedagogie postmoderna [Postmodern pedagogy). Iaşi, România: Institutul European.

Varela, F. J. (1991).The embodied mind. Cambridge, USA: MIT Press.

Woods, J., \& Walton, D. (1992). Critique de l' argumentation. Paris, France: Editions Kimé. 